\title{
Idiopathic Non-ischemic Priapism in a 7-Year-Old Boy
}

\author{
Eiji Hisamatsu, ${ }^{*}$ Hiroko Suzuki, Teruhisa Uehara, Kaoru Yoshino
}

Department of Urology, Aichi Children's Health and Medical Center, Japan

\section{ABSTRACT}

Non-ischemic priapism is a rare condition in children. Perineal trauma is the most common cause of this condition. We report a 7-year-old boy with idiopathic non-ischemic priapism that resolved spontaneously after four weeks of watchful waiting.

\section{Key words: Idiopathic; Non-ischemic; Pediatrics; Priapism}

Correspondence*: Eiji Hisamatsu, Department of Urology, Aichi Children's Health and Medical Center, Japan

E-mail: fpsfd412@yahoo.co.jp

Submitted: 06-06-2017

Conflict of Interest: None
(C) 2017, Hisamatsu et al.

Accepted: 28-08-2017

Source of Support: Nil

This is an open-access article distributed under the terms of the Creative Commons Attribution License, which permits unrestricted use, distribution, and reproduction in any medium, provided the original work is properly cited.

\section{INTRODUCTION}

Priapism is a full or partial erection that continues more than four hours beyond sexual stimulation and orgasm or is unrelated to sexual stimulation. Ischemic priapism is characterized by little or no cavernous blood flow. In contrast, non-ischemic priapism is caused by unregulated cavernous arterial inflow.[1] Non-ischemic priapism is a rare condition in children.[2] We report a case of nonischemic priapism in a child with no apparent cause.

\section{CASE REPORT}

A 7-year-old boy was referred to our center with abnormal penile erection persisting for two days. He complained of mild pain without voiding symptoms. He had no history of trauma. Physical examination showed that the proximal two-third of the penis was tumescent with slight tenderness. Blood tests revealed no evidence of sickle cell anemia or other hematological diseases. Color Doppler ultrasonography (CDUS) showed increased inflow from the cavernous artery toward the corpus cavernosum on the right side. He was diagnosed as a case of non-ischemic priapism of unknown etiology. Spontaneous detumescence was noted after four weeks. At follow-up evaluation 16 months after diagnosis, he had not developed a recurrence. Follow-up CDUS revealed only a small arterio-cavernous fistula at the base of the right corpus cavernosum (Fig.1).

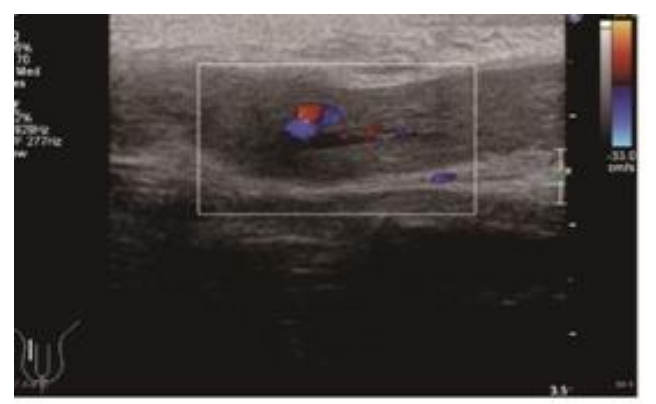

Figure 1: Doppler study showing small arterio-cavernous fistula.

\section{DISCUSSION}

Non-ischemic priapism usually occurs due to perineal trauma such as a straddle injury. A few cases of pediatric non-ischemic priapism associated with sickle cell disease, leukemia, and Fabry's disease are also reported.[2] There are three reported pediatric cases of non-ischemic priapism of unknown etiology.[3-5]. In our patient there was no history of trauma. 
A corporal blood gas analysis by aspiration is usually recommended in the emergency evaluation of priapism because it differentiates ischemic from non-ischemic priapism. However, a corporal aspiration is invasive especially for children. Several authors have reported that a corporal aspiration is not universally recommended and is thought to be unnecessary if the diagnosis is clear.[68] We did not perform the corporal blood gas analysis on our patient because the diagnosis was clear according to the clinical course, physical and CDUS findings.

The initial management of non-ischemic priapism is observation because spontaneous resolution may occur.[1] In previous reports of seven children with non-ischemic priapism due to trauma, spontaneous resolution occurred in 5 days to 9 months (median 2 weeks) after the onset.[2] In the two children with non-ischemic priapism of unknown etiology, the priapism resolved spontaneously in 25 days after the diagnosis. Another patient underwent embolization of the arterio-cavernous fistula after three weeks of watchful waiting. $[4,5]$ However, there is no clear indication of the acceptable safe duration of watchful waiting in pediatric or adult patients.

We should consider the possibility of idiopathic non-ischemic priapism when managing children with no history of trauma. It is important to rule out underlying diseases as well. The initial management of pediatric non-ischemic priapism is observation because spontaneous resolution may occur.

Consent: Authors have submitted signed consent form from legal guardians of the patient for use of clinical material in this manuscript. The Consent form is available with Editorial office.

Authors' Contribution: All authors contributed equally in concept, literature review, and drafting of the manuscript and approved the final version of this manuscript.

\section{REFERENCES}

1. Broderick GA. Priapism. In Campbell-Walsh Urology. 11th edition. Edited by Wein AJ, Kavoussi LR, Partin AW, Peters CA. Philadelphia: Elsevier; 2016: 669-91

2. Mockfold K, Weston M, Subramaniam R. Management of high-flow priapism in paediatric patients: a case report and review of the literature. J Pediatr Urol. 2007; 3: 404-12.

3. Stock KW, Jacob AL, Kummer M, Zimmermann U, Steinbrich W. High-flow priapism in a child: treatment with superselective embolization. Am J Roentgenol. 1996; 166:2902.

4. Resim S, Sahinkanat T, Karabiber H. High-flow priapism of unknown etiology in a prepubertal boy. Pediatr Int. 2004; 46: 492-3.

5. Mahawong $\mathrm{P}$, Srisuwan $\mathrm{T}$. Idiopathic high-flow priapism in a pediatric patient. J Pediatr Urol. 2011; 7: 92-4.

6. Miller SF, Chait PG, Burrows PE, Steckler RE, Khoury AE, McLorie GA, et al. Posttraumatic arterial priapism in children: management with embolization. Radiol. 1995; 196:5962.

7. Roussel G, Robert $Y$, Mahe P, Soret R, Legeais D, Meria P, et al. High-flow priapism in children: immediate treatment by selective embolization. Eur J Pediatr Surg. 2001; 11:350-3.

8. Hatzichristou D, Salpiggidis G, Hatzimouratidis K, Apostolidis A, Tzortzis V, Bekos A, et al. Management strategy for arterial priapism: therapeutic dilemmas. J Urol. 2002; 168:2074-77. 